Khazanah: Jurnal Studi Islam dan Humaniora

ISSN: 0215-837X (p); 2460-7606 (e), Vol. 17 (1), 2019, pp 1-24

DOI: $10.18592 /$ khazanah.v17i1.3002

Submit : 21/06/2019 Review : 27/06/2019 Publish : 30/07/2019

\title{
PASSING AS A FORM OF ADAPTATION: THE ISLAMIC NUANCES OF THE CHRISTIANS AND CATHOLICS
}

\author{
Riza Saputra \\ Center for Religious and Cross-Cultural Studies, Gadjah Mada University \\ Rizasaputra2512@gmail.com
}

\begin{abstract}
This study aims to discuss the phenomenon of the Christians and Catholics that imitate Islamic expressions in Banarjoyo village. The cordial relationship among Muslims, the Christians and Catholics of Banarjoyo village provide new nuances on the concept of passing. Using field research and collecting data through participant observation and in-depth semi structured interview techniques, the study reaches the following results: Christians and Catholics adaptation with Muslims activities in Banarjoyo village undergirds on three aspects of social interaction, namely parallel, associative, and cooperative. The processes of Christians and Catholics' interaction and participation within Muslims activities are the causes of the identification, and imitation of Islamic expressions. The main factor of the Christians and Catholics imitation of Islamic expression is because of their role identity and their feeling dissimilar that further make them try to assimilate with the dominant Islamic context. This assimilation and adjustment of Christians and Catholics behaviors as well as Muslims is what we called as "Passing as a form of adaptation."
\end{abstract}

Keywords: Passing; Adaptation; Christians; Catholics; Islamic expressions

\section{Introduction}

In social exchange theory, Thibaut and Kelley conclude that individual behavior may susceptible be affected by his partner. In addition, Gidden expounds that our behavior is constructed by the environment and how we relate to that environment. ${ }^{1}$ Social interaction is defined as a relationship between two or more individuals, which affects an individual's behavior, alter or affect any other individual or vice versa. In the cognitive process, social interaction may build "shared relational reasoning" between an individual and the possibility of solving the problem

${ }^{1}$ Hechavarría, Diana M. "Mother nature's son? The impact of gender socialization and culture on environmental venturing." International Journal of Gender and Entrepreneurship 8, no. 2 (2016): 137-172. 
simultaneously. ${ }^{2}$ This suggests that social interaction is a stimulus for the actions and considerations of other individuals who became his partner.

The notion above denotes that a person has not one-personal self, but rather a several selves that correspond to widening circles of group membership. Works such as Griffith's "The Church in the Shadow of the Mosques" delineates the Christian's behavior and intellectual in Islamic countries is much affected by the condition of Arabic culture and social context therein. Indonesia in contrast is not regarded as an Islamic country, yet its population is one of the countries with the largest Muslim population in the world. Indonesia is enriched with six religious traditions: Islam, Christianity, Catholicism, Buddhism, Hinduism, and Kong $\mathrm{Hu} \mathrm{Cu}$, and many other religions and beliefs. The pluralistic society and religious diversity in Indonesia face the challenges to find out what is an appropriate equilibrium between people's commonality and people differences. ${ }^{3}$

Christians, Catholics and Muslims interactions have taken a role in Indonesia's interreligious discussion. Christianity and Catholicism are considered to be the second dominant religious faith in Indonesia, but, in some places, the Christians and Catholics are still found to be the minority. As well as in Banarjoyo village, East Lampung, wherein, thirty Catholic and thirty-five Christians are presently living in Banarjoyo village, that is, the village with a Muslim demographic majority. Banarjoyo village comprises $98.2 \%$ of Muslims, $0.82 \%$ of Catholic, and $0.96 \%$ of Protestant. Indeed, this significant difference between the Christians and Muslims number in Banarjoyo village requires a balance in social and religious life.

However, the core challenge for the Christians and Catholics in Banarjoyo is not confined to the way of their interaction with Muslims, but on the impact of this interaction and the models which are provided by the environment. As Moen and Garbarino expound that the living

${ }^{2}$ Pablo Fernández-Berrocal and Carlos Santamaría, "Mental Models in Social Interaction," The Journal of Experimental Education 74, no. 3 (April 1, 2006): 246, https://doi.org/10.3200/JEXE.74.3.227-248.

${ }^{3}$ Hefner, Robert W. "Introduction: Indonesia at the crossroads: imbroglios of religion, state, and society in an Asian Muslim nation." In Routledge Handbook of contemporary Indonesia, pp. 3-30. Routledge, 2018. 
conditions of the neighborhood and the community gives those experiences on which to build their personality. This idea indicates that the condition of the environment is decisive on one's individual character and behavior.

Banarjoyo village is surrounded by daily events that provide models. Heyes mentioned that humans tend to imitate the actions of their social partners, and such imitative behavior is seen as a hallmark of social interaction. ${ }^{4}$ In Banarjoyo village, the influences of Islamic expressions are adopted and imitated by some of the Christians and Catholics, such as using of the Qur'an as an amulet, utilization of Islamic and Arabic phrase in colloquial expressions, memorizing of verses of the Qur'an, hadith, and Islamic prayer, fasting during the month of Ramadhan, avoiding from eating dog and pork, and etc. All of these examples delineate the role of environment and social context of Banarjoyo village, wherein Islam is as a dominant.

The Christian and Catholic's adaptation and utilization of Islamic expression indicates as a part of "passing," it literally means to move, to change from one state condition to another, to go past or across, to go beyond the limit of, to surpass or exceed. It is a product of social practice, which means that an individual who intends to pass, he/she must imitate or adapt to his/her new condition and new style. Thereof, to know more how the concept of passing in Banarjoyo village, this research will look at how do the Christians and Catholics adapt with Muslims majority in Banarjoyo village? Why do the Christians and Catholics of Banarjoyo imitate the Islamic expressions? And how the process of "passing" takes its role in the context of the Christians and Catholics of Banarjoyo village?

Banarjoyo is a small village in East Lampung, $5 \mathrm{~km}$ from the center of Metro City. This village is a part of Kecamatan Batanghari. It takes 2829 hours trip by bus from Jombor station at Yogyakarta. Currently, there are four communities (dusun) in Banarjoyo village. Many people of Banarjoyo village commonly call this place with the number "the village

${ }^{4}$ Cecilia Heyes, “Automatic Imitation,” Psychological Bulletin, 463-483, 137 (2011), https://doi.org/DOI: 10.1037/a0022288. 
46 (forty-six)" rather than its formal name "Banarjoyo." That's why the villagers looked confused when I asked if the name of their village was Banarjoyo. Banarjoyo village is located in Batanghari district that is formed most of the trees and rice fields. The land in Banarjoyo village is quiet fertile, many plants and fruits, such as chocolate, durian, lengkeng, and notably paddy grown in this village. My arrival in Banarjoyo village coincided with the harvest time. Thus in the morning, this place was very quiet, because the farmer went to the rice field, and children went to the schools. In the middle of this village, there was a football field, wherein children and young men of Banarjoyo village played football. This football field sometimes used for Ied Prayer, big days for Muslim (Id Fitri and Id Adha). Banarjoyo village is famous with its market, and this market is located in front of Masjid Jāmi Batanghari

The Christians and Catholics participation within Muslim religious activities and the cordial relationship among them offers an ideal canvas for studying issues of the Christians and Catholics' adaptation with Muslims majority in Banarjoyo village. Therefore, this research expect can give a new insight for the cluster of Christians and Catholics rapport with Muslims, especially in the discussion of social life and religious diversity in Indonesia. ${ }^{5}$ To facilitate our analysis on the Christian and Catholics' interaction with Muslims, and what are the causes of the Christians and Catholics imitation of Islamic expressions. In this case, we attempted to integrate two theories of interactions - the first of which is symbolic Interactionist and the second is social interaction. Symbolic interactionism is very appropriate to learn the internal factors that account for the Christians and Catholics behaviors in Banarjoyo village.

\section{Method}

This research design was qualitative, using field research, and collecting data through participant observation and in-depth semi-

${ }^{5}$ According to the symbolic interaction theory, the process through individual identity is constructed centers around three concepts: Role taking, role identity, and the looking glass-self. Role taking is responsive to the expectation of "significant others" are the role players with whom we have close personal relationships. Role identity is the image we have of ourselves in a specific social role. See Peter J. Burke, "The Self: Measurement Requirements from an Interactionist Perspective," Social Psychology Quarterly 43, no. 1 (1980): 18-29, https://doi.org/10.2307/3033745. 18 
structured interview techniques. Field research is central to research significance where there is relatively little knowledge about the topic, with only a few publications. ${ }^{6}$ The purpose of participant observation is to observe and understand how Christians and Catholics' cooperation with Muslim in Banarjoyo village, and more specifically to glean insight on the role of social and cultural context that enable the writer to depict the form of the Christians and Catholics passing in Banarjoyo village.

In the collection of data, I combined a qualitative method, conducting semi-structured interviews. The interview analyzed the Christians and Catholic interaction with Muslim and their participation in Muslim religious practices. The other things are their personal background, their understanding and knowledge about Islam, experiences with Muslims and the respondent's assessment of Christians and Catholics relation with Muslims in Banarjoyo village. Respondents were selected using purposive sampling. My primary purpose was to select the Christians and Catholic who active socially and expressed the Islamic expressions in their daily life. I conducted in-depth semi-structured interviews with a total of 13 respondents, including men and women from Christians and Catholic and lasted from 30 minutes to 3 hours. Three of the interviewees were formerly Muslims who had converted to the Christians, and one of the interviewees was a Catholic who had converted to Islam.

\section{Passing and the Three Methods to Pass}

"Pass" literally means to move, to change from one state condition to another, to go past or across, to go beyond the limit of, to surpass or exceed. This term also has metonymic associations with death or "passing away" that is, a move from life condition to the death. ${ }^{7}$ In addition, Samira Kawash indicated that the verb form of the Latin "passus" means "to step, pace, and walk." Therefore, passing would necessarily involve geographical movements which means the passer has to abandon an

${ }^{6}$ Royce Singleton \& Bruce. C. Straits. Approaches to Social Research. (New York: Oxford University Press, 1999), 323.

${ }^{7}$ S.P. Wright \& Ernestine Pickens Glass. (Ed.). Passing in the Work of Charles W. Chesnutt. (United States: University Presses of Mississippi, 2010), 43. 
environment where his or her "true identity"- that is parentage, legal status, and the like-is known to find a place where it is unknown. ${ }^{8}$

Referring to the historical analysis, it is hard to say when exactly the phenomenon of passing first evolved; however, most likely one may well argue that it coexisted with the cultivation of miscegenation. ${ }^{9}$ However, Hostert argues that passing does not refer only to the sociological phenomenon of American racial history and miscegenation. ${ }^{10}$ The term passing has an extensive meaning, there is gender passing, class passing, age passing, and etc., ${ }^{11}$ which denotes that passing is not limited only to the racial discussion or to the geographical movement.

Passing is a product of social practice, the ability of individual or communal to adopt the appearance and social identity of a category that is not constructed as his or her natural biological and group of social home. ${ }^{12}$ It means that an individual who intends to pass, he/she must adapt to his/her new condition, and certainly, it depends on the context and social situation wherein, an individual tries to embroil within.

Based on the literatures discussing about passing, it can be classified that there are three methods to operate passing: the first is passing through "performativity" or performing of the trope another identity, the second is by "changing physically and culturally," and the third is by "assuming another identity." These three methods of passing cultivate as a way to embroil with another group of community. However, passing-conscious

${ }^{8}$ Barbara Fuchs, Passing for Spain: Cervantes and the Fictions of Identity (Urbana: University of Illinois Press, 2003), 3.

${ }^{9}$ Robert Wetzorke, Passing and the Problem of Identity in Afro-American Literature: A Study of N. Larsen and J.W. Johnson (GRIN Verlag, 2010), 5.

${ }^{10}$ Anna Camaiti Hostert, Passing: A Strategy to Dissolve Identities and Remap Differences, trans. Christine Marciasini, 1 edition (Madison N.J.: Fairleigh Dickinson Univ Pr, 2007), 14.

${ }^{11}$ B. Kroeger, Passing: When People Can't Be Who They Are. (United States: Public Affairs, 2003), 5.

${ }^{12}$ Mireille Rosello, "Dissident or Conformist Passing: Merzak Allouache's Chouchou," South Central Review 28, no. 1 (May 27, 2011): 4. 
and unconscious-at once aroused ambivalence because of crossing the boundaries of identity. ${ }^{13}$

The first method of passing is through performativity, including imitation and adoption. The passer who wants to embroil and claim as a part of that identity must adopt and evince the parts of other's colloquial language, behaviors, dress, and etc. As Butler ${ }^{14}$, Caughie ${ }^{15}$, and Silvermint ${ }^{16}$ have conceptualized, passing necessarily refers to the ways in which subjectivity is performed in lived reality. The performativity does not only refer to the visible performance, but also to the unseen aspects, such as the voices of musical instruments and colloquial expressions.

The second method is by changing of ourselves either physically or culturally. Such as in regard to the discussion of transgender, Judith Butler mentions that "passing" fully subverts the distinction between inner and outer psychic space. ${ }^{17}$ If in the first method, the performativity "passing as" is considered by Caughie as metaphorical meaning. However, in this second method, an attempt to change physically-inner and outer considered for those who want to be truly themselves. ${ }^{18}$

The third method is the complementary and supplemental of the first and the second method. That is, passing by assuming the identity of

${ }^{13}$ Pamela L. Caughie, "Passing as Modernism," Modernism/Modernity 12, no. 3 (September 9, 2005): 387, https://doi.org/10.1353/mod.2005.0079; Sands, Justin. "Passing through customs: Merold Westphal, Richard Kearney, and the methodological boundaries between philosophy of religion and theology." Religions 7, no. 7 (2016): 83.

${ }^{14}$ Butler, Janine. "The Visual Experience of Accessing Captioned Television and Digital Videos." Television \& New Media (2019):1.

15 Caughie, Pamela L., Emily Datskou, and Rebecca Parker. "Storm clouds on the horizon: feminist ontologies and the problem of gender." Feminist Modernist Studies 1, no. 3 (2018): 230-242.

16 Silvermint, Daniel. "Passing as privileged." Ergo, an Open Access Journal of Philosophy 5 (2018).

${ }^{17}$ Judith Butler, Gender Trouble: Feminism and the Subversion of Identity (Routledge, 2011), 137.

${ }^{18}$ Passing by changing of our physic and renewing an identity much refers to the discussion of transgender, woman passes to the man and on the contrary man passes to the woman. This passing is not definite to the metaphoric meaning, but, the passers decided that identity is proper for them. B. Kroeger, Passing: When People Can't Be Who They Are. 2, 
another. This method of passing has usage to identify oneself as another race. ${ }^{19}$ Although, by assuming the identity of another, an individual can pass, however, this method considers as not enough for individual who want to pass. There must be an involvement and imitation in order to identify as a part of that group member. An individual who pass only by assuming the identity of another and do not change his own performances may realize easily as a betrayer of that group member, since, his passing does not reflect the identity of that other group.

\section{Christians and Catholics in the Realm of Muslim Majority}

The main discussion of the majority and the minority often distinguish both of these two as social disequilibrium. However, the significant different number of the Christians, Catholic and Muslims in Banarjoyo did not buttress them to intertwine relationship. Most of the Christians and Catholics of Banarjoyo said their relationships with Muslim were harmonious, even, most of them considered Muslims were already like their family, yet, only a few of them were not integrationist. At Christmas time, many Muslims came to the Christian's houses, and when the Ied days of Islam, the Christians also came to the Muslim's houses. This interrelationship indicates the presence of togetherness and an openness relationship between the Christians and Muslims of Banarjoyo village.

\begin{tabular}{clllll}
\hline No. & Name of Dusun & \multicolumn{4}{c}{$\begin{array}{c}\text { The Number of Population in the End of the } \\
\text { Month, March, 2014 }\end{array}$} \\
\hline & & The Number & \multicolumn{2}{c}{ The Number Per-Souls } \\
\cline { 3 - 6 } & & Per-House & Male & Female & Male+Female \\
\hline 1. & Adirejo & 254 & 496 & 472 & 968 \\
\hline 2. & Gadingrejo & 278 & 504 & 480 & 984 \\
\hline 3. & Boyolali & 224 & 445 & 436 & 881 \\
\hline 4. & Pacitan & 211 & 401 & 404 & 805 \\
\hline & Total Number & 967 & 1846 & 1792 & 3638 \\
\hline
\end{tabular}

Table 1: The Number of Population in Banarjoyo Village.

${ }^{19}$ Ayanna Thompson, Passing Strange: Shakespeare, Race, and Contemporary America by Ayanna Thompson (Oxford University Press, 1700), 9. 
Passing as a Form of Adaptation: The Islamic Nuances of the Christians and Catholics

\begin{tabular}{lccc}
\hline \multicolumn{1}{c}{$\mathbf{2 0 1 4}$} & Number of People & Number Per-House & Percent \\
\hline Islam & 3573 & 946 & 98,2 \\
\hline Christians & 35 & 13 & 0,96 \\
\hline Catholic & 30 & 8 & 0,82 \\
\hline Total & 3638 & 967 & 99.9 \\
\hline
\end{tabular}

Table 2: The Number of Population in Banarjoyo

Village based on Religion.

The table above describes that the different numbers of the Christians, the Catholics and the Muslims of Banarjoyo village. Based on this table, it can be deduced that Banarjoyo village is dominant of Muslims. However, these significantly different numbers does not much affect the faces of the Christians and Catholics in Banarjoyo village. They verbalized that they felt happy to communicate and associate with Muslims. Cooperation and mutual aid were already manifested in their everyday life. It shows what Knitter says about commitment and openness to others not merely as a dialogue but end up as a tolerance. ${ }^{20}$

The small number of the Christians and Catholics in Banarjoyo village requires them to establish a good relationship with Muslim neighbors. The behavior of the Christians and Catholics in Banarjoyo village is regulated by the role of the environment and the surrounding community. Therefore, a lot of Christians and Catholics in Banarjoyo village try to adapt and equalize their behavior to what is done by many people, and especially Muslims.

Environment plays its role in the formation of social actors which Gabarino calls it as 'environmental press.' it means, "All forces at work within the environment. These forces generate psychological momentum

${ }^{20}$ Paul F. Knitter, "Christian Attitudes toward Other Religions: The Challenge of Commitment and Openness," Prajñā Vihära 5, no. 1 (2004): 177; See also: Adams, Katharine S., Jeremy R. Tost, Mark A. Whatley, Meghan C. Brown, Brendan J. Dochney, Jessica M. Taylor, and Mary H. Neal. "Relationship of Christian beliefs to attitudes toward people with mental illness." American journal of psychotherapy 71, no. 3 (2018): 104109. 
that guides individuals in a particular direction. ${ }^{21}$ As time goes on and through the process of interaction, the individual behavior tends to become compatible with the demands of the environment.

The number of houses worship in Banarjoyo village represents the environmental condition and the religious devotees. There are two churches in Banarjoyo village: 1) the Catholic Church of Santa Maria Stasi Batanghari, 2) the Christians church, Southern Sumatera or Gereja Kristen Sumatera Bagian Selatan (GKSBS). ${ }^{22}$ The other parts of the rest of Banarjoyo environment is filled with the mosques and small mosques. There are 4 Mesjid (mosques), and 10 Musholla (small mosques) in Banarjoyo.

The large number of the mosques was very influential to the peripheral condition of Banarjoyo village, and notably to the Christians and Catholics devotees. The Christians in Banarjoyo said their children usually followed their Muslims friend to the mosque, either playing or participating in religious activities, such as 'ngaji' (learning and reading) the Qur'an. The Christians and Catholics who dwelt in Banarjoyo village admitted that they had already familiar with 'adzan' (summon to prayer) from the mosque loudspeaker. Moreover, during the month of Ramadhan, the Christians frequently heard to the Qur'anic recitation and Islamic religious lectures, both from the mosques and small mosques.

A huge number of Muslim population in Banarjoyo also affect to the Christians and Catholics' education. The Christians and Catholics student learn in public school, wherein an Islamic nuance is very strong. In Junior high school, before the student began the lessons, they firstly read the Qur'an together. Although, the Christians and Catholics did not take the Qur'an and participate in reading, they were sitting among

${ }^{21}$ James Garbarino, Raising Children in a Socially Toxic Environment, 1 edition (San Francisco: Jossey-Bass, 1999), 25.

${ }^{22}$ GKSBS (Gereja Kristen Bagian Selatan) begun from the existence of GKJ (Gereja Kristen Jawa). In 6 August 1987 Sinode GKJ of region 1 decided GKSBS as the church which can exist alone. However, although the GKSBS has a connection with the GKJ, the adherents of GKSBS have a various tribes and it is not limit only for the Javanese. 
Muslims friend, hearing and observing to their Muslims friend's recitation of the Qur'an. The students read the Qur'an nearly fifteenth minutes every day before the school start. In kindergarten, the Christians and Catholics also involved with the traditions of Islam, such as reading the prayer together before they start the lessons, and before they eat. Because the Christians and Catholics students in kindergarten were still very young, they just followed happily reading the prayer together with their friends. The similar condition could also be found in elementary school of SD Negeri 1 Banarjoyo, the students read the Islamic prayer before they started the lesson. Moreover, since the first grade, the Christians students in elementary school have learned and participated in Islamic Studies and BTQ (reading and writing the Qur'an). There was no discrimination between the Christians, Catholics and Muslims students in Banarjoyo village. Thus, they could feel togetherness in that school.

\section{Christians and Catholics Rapport with Muslims}

Ibu Suriati explained that there were some Muslims complained to the halalness of the foods, whenever are cooked by the Catholic. Thus, she was worried if the foods would not be received by her Muslims neighbor. Indeed, by asking Muslim's help in cooking, she expected that all Muslim neighbors might receive her food distributions. It shows that the cooperation among Muslims, Catholic and the Christians has formulated an unpretentious manner to solve the difference on dietary problems. Moreover, Muslims, Christians, and Catholics in Banarjoyo mutually give their contribution each other. Muslim's help has built a positive in the Christian's perspective, and vice versa, as Pakde Manto told that Christians-Muslims relation entwines very well and it supports each other.

The Christians and Catholics visited Muslim's houses when Ied days, whereas, Muslims rejoined attending to the Christians and Catholics houses at Natal day. The motif here echoes the reciprocal relationship that is evoked by social interaction. The mutual relationships between the Christians, Catholic and Muslims enhance the value of proximity and 
closeness, they fervently apt to interlace with one another, because they were attentive to the habit of social and cultural context. Silaturrahim (Extending relationship) that is interlaced by the Christians, Catholics, and Muslims benefits to the community of Banarjoyo the strength to rise above selfish needs, to let go of their differences and to really size up what is important in their life - serenity of mind and kindness towards others.

Referring to Selman, the relationship which is taken by an individual has potential to understand and aware of other existences, it is able to produce a sense of happiness, empathy, and delighted with our partners. The rapport which is knitted by the Christians and Catholics with Muslims influences not only in the way of interaction, but also in a personal cognition. Such as the Christians and Catholics in Banarjoyo village felt happy when Muslims celebrate Ied Adha and Ied Fitri. This feeling of happiness is an effect of social interaction that affects personal empathy.

Since people in Banarjoyo village have been mingling with one another, The number of fanatic is slowly disappearing, Pakde Saryono enunciated that only one Muslim who is still fanatic. ${ }^{23}$ Another opinion was mentioned by Pakde Manto that the number of Muslim fanatic in Banarjoyo was very small, only a few of them. Based on the Christian's identification there are three characteristics of fanatic: 1), an apologist, a person who holds firmly to his/her religious teaching, 2), a nonnationalist, a person who does not want to entwine relationship with others, 3), an indifferent one, a person who does not care for the others. Indeed, all of these have their own reasons why they do such things.

Christians and Catholics' relationship with Muslims does not only present in social interaction. They also participate with Muslim religious activities. Most of the Christians of Banarjoyo take part in local Muslim religious activities, such as, kendurenan (Salvation program), yasinan (reading the surah yasin of the Qur'an), aqiqahan (naming ceremony for a new birth), ngaji (reading and learning the Qur'an), and takbiran (glorifying God with the sentence Allahu Akbar). The presences of the Christians and Catholics in Muslims local religious activities were supported by the notion

${ }^{23}$ Interview with Pakde Saryono on March, 14 2014. 
Passing as a Form of Adaptation:

The Islamic Nuances of the Christians and Catholics

of respect and homage to the Muslims, as Pakde Saryono and Pak Marwoto mentioned that the Christians were almost never absence in these Muslim religious activities.

\section{Christians and Catholics Imitation of Islamic Expressions}

Three papers with the same Qur'anic writings lined in a part of windows of the Catholic's houses. The writing was a collection of verses of the Qur'an which consist of Surah Ghafir and Surah An-Nisa. Pakde Pomo, an elder of the Catholic who wrote the verses of the Qur'an justified the using of the Qur'anic verses was as an amulet to avoid evils. The Catholics want to protect themselves from the bad things, as well as Muslims. The notion "as Muslim" is the central delineation how the Catholics of Banarjoyo have adopted the part of Islamic expressions in their life. Moreover, it also shows the Catholic agreement on Muslims effort in order to protect their houses from evil. In this case, imitation might be due to a more general effect of the Catholics agreement to the social context and situation of Banarjoyo village.

The dominant Islamic culture in Banarjoyo village encourages the Christians and Catholics to suit their habit to involve in this dominant culture. Moreover, the need to belong is a prominent quality of the human species. Most of the Christians and Catholics of Banarjoyo imitate Islamic phrases in colloquial expression, such as Assalamu'alaikum, Innalillabi wa Inna Ilaibi Raji'un, and InsyaAllah. This imitation is one route for the Christians and Catholics of Banarjoyo village to adapt within the demographic of the Muslim majority. In addition, Christians and Catholics participation in Islamic studies in public school and local Muslim religious activities has made some of them memorize verses of the Qur'an, hadith and Islamic prayer. Some of them also practice the Islamic teachings, such as fasting during the month of Ramadhan, and refraining from eating pork and dog. Some of them also used Islamic dress, such as Islamic shirt and black cap when they participate within Muslim religious activities. All of these expressions denote the boundary that has been passed by the Christians and Catholics of Banarjoyo village. 
Riza Saputra

\section{Passing in the Context of the Christians and Catholics}

Most of passing studies expound that passing as methods to change and grow the self and personality. ${ }^{24}$ However, social exchange theory denotes that individuals may pass because of the influence of the society and the environment. ${ }^{25}$ Since the Christians and Catholics of Banarjoyo interact with Muslims and participate within Muslims religious activities, many of them passed their habit as well as Muslims. Moreover, the context of Banarjoyo village is dominant with Islamic local culture and the huge of the number Muslim population. Thereof, the society and social environment of Banarjoyo village takes a big role for the Christians and Catholics' behaviors and principles.

Social interaction shows an alteration of individual behavior. The processes of social interaction moreover indicate as individual adjustment (imitation, identification, sympathetic and empathetic understanding) to the social and environmental context. It forms individual's adaptation that requires an acceptance and recognizance from another. Likewise, passing is also one of the forms of adaptation where someone tries to adjust his/her behavior with the social and cultural context. In simple word, there is an alteration of someone's behavior because of passing and adaptation, including the principles of life and behavioral activities. ${ }^{26}$

${ }^{24}$ Mang, Pum Za. "The Politics of Religious Conversion among the Ethnic Chin in Burma." Studies in World Christianity 24, no. 3 (2018): 188-211; Watson, Nick J., and Andrew Parker. "The mystical and sublime in extreme sports: Experiences of psychological well-being or Christian revelation?." Studies in World Christianity21, no. 3 (2015): 260-281; Polley, Gabriel. "From Karm al-Khalil to Kerem Avraham: A British Settler-Colonial Outpost Near Jerusalem in the Nineteenth Century." Journal of Holy Land and Palestine Studies 18, no. 1 (2019): 51-73.; Barberia, Itxaso, Ramon Oliva, Pierre Bourdin, and Mel Slater. "Virtual mortality and near-death experience after a prolonged exposure in a shared virtual reality may lead to positive life-attitude changes." PloS one 13, no. 11 (2018): e0203358.

${ }^{25}$ Marie Wong, Stephanie. "A Society Apart: Rural Chinese Catholics and the Historiography of 'Otherness'." Studies in World Christianity 22, no. 2 (2016): 86-104.

${ }^{26}$ Mercadante, Linda. "Belief without borders: Inside the minds of the spiritual but not religious." In Being Spiritual but Not Religious, pp. 110-127. Routledge, 2018. 
The ability of the Christians and Catholics to take the perspectives of another is also one of the factors that changed their reaction and opinion to the Muslims. It shows that symbolic interactionism theory has provided meaning for individuals who change their habit. In general idea, symbolic interactionism theory suggests the importance of others, including their behaviors.

Passing as a form adaptation can be seen through the Catholic and Christian's participation within Muslim religious activities, wherein they have to follow the systems, such as showing a respect when they listen to the Qur'anic recitation, even some of them wore a black cap and suited their dress by wearing a Muslim shirt. There are the notions of "before," "after" and "during" the process which relates to the passing and adaptation. The behaviors and personality change shows individual reaction to the condition of social and environment. The Christians and Catholics of Banarjoyo changed their behavior, colloquial expressions, and worldview after they embroiled with the Muslims majority and dominant Islam. As well as social change theory, the factor of the Catholic and Christians passing to the Islamic nuances is also advocated by some aspects:

Firstly, Cultural factor: the dominant of local Islamic culture in Banarjoyo has given direction to the Christians and Catholics, and determines what they need to do in order to maintain social equilibrium of Banarjoyo. Sharma mentions that the culture will give the limits beyond which social and personal change cannot occur. ${ }^{27}$

Secondly, Population factor: the significant different number of Muslims, the Christians and Catholics of Banarjoyo has an effect upon the social activities and organization as well as customs and traditions, and etc. a change in the ratio Muslims, Catholic and the Christians have an effect on individual and self-construction. Thirdly, Environmental factor: the demographic of Muslim majority and social condition of Banarjoyo emphasized the impact upon the growth and construction of Catholic and

${ }^{27}$ Rajendra Kumar Sharma, Social Changes and Social Control (New Delhi: Atlantic Publishers \& Distributors, 2007), 2. 
Christian's behavior, habit, and their worldview. Fourthly, Psychological factor: the cause of Individual changes is the psychology of man himself. ${ }^{28}$

All of these factors represent some aspects that may influence the Christians and Catholics standpoint. The dominant of Islamic culture, tradition, and the number of the population make the Christians and Catholics realized that they need to adapt with Muslims, and with the peripheral living condition of Banarjoyo village. Passing as a form adaptation in the context of the Christians and Catholics of Banarjoyo village raises some categories:

Firstly, adaptation and assumption of another: as we already discussed, "passing" considers as an act of "assuming" the identity of another. However, in the case of the context of Banarjoyo village, the Christians do not assume their identity as Muslims. Assuming the identity of another delineates that passing is advocated by individual passer who intend to embroil with that group community or as Caughie notes the "desirable identity," whereas, "assumption of another" means that the characteristic of individual's passer associates with an assumption of another person, whether from individual's observation of the passer performance, behavior, or habit.

The Christians and Catholic's performing of Islamic expressions can be seen through their participation within Islamic local religious activities. For instance, in kendurenan program, some of the Christians and Catholic wore Islamic dress and kopiah (an Islamic cap). We observe that it might difficult to identify the Christians and Catholics for those who did not recognize that they were the Christianity. The Christians and catholic realized that they had mingled with Muslims, thus, their utilization of Islamic signifying is a form of their adaptation within the Islamic local religious activity.

Although some of the Christians and Catholic wore Islamic signification identity, but, they realized that their identity were the Christianity. The Christians and Catholic told that because they aware their identity were the Christianity, thus, most of them did not participate in reading the whole of Arabic recitation, they just heard and embroiled with

${ }^{28}$ Sharma, 3. 
the other attendees. It shows that although the Christians and Catholics had passed through their performance and participation within a local Muslim religious activity, yet, they still admitted their "role identity" as the Christians and Catholics.

Imitation takes a form of performativity which is one of the methods for individual to pass into another group. The Christians of Banarjoyo do not use imitation as a method to pass or to pretend their identity as another. Thus, it may true that they have passed because they imitated Islamic phrase in colloquial expression. However, imitation is not only a method; it is one of the social interaction processes, wherein individuals will get influences from another in social interaction. The Christians and Catholics imitate the Islamic expressions, yet, they do not deny their identity as the Christians and Catholics. Passing by imitation of the Islamic signifier identity is a form of the Catholic and Christian's adaptation to the dominant Muslim culture in Banarjoyo.

Secondly, adaptation and different purposes of passing: The motivation of passing mostly associates with the purpose to gain the privileges, sympathy, and rewards from another person. However, in the discussion of the Catholic using the Qur'an as an amulet, the purpose of passing is not because they intended to gain the privilege, reward, and sympathetic gaze from Muslim, yet, it was because they have a similar purpose as well as Muslims of Banarjoyo, that is, to protect themselves from wickedness and robbing which shows the influence of Islamic local culture that embed in the Catholic's worldview of Banarjoyo village.

Catholic use the Qur'an as an amulet has also shown the form of passing, it shows the notion of Islamic signifier identity that they used. Their utilization of the Qur'an as an amulet does not mean that they aim to pass to the Islam, but their utilization of the Qur'an as an amulet denoted that they have passed their habit and worldview as well as Muslims. The Catholics realized that before they migrate to the Banarjoyo village, they did not acquaint the knowledge of using the Qur'an as an amulet, but since they observed that most of Muslim used the Qur'an for protection, they began to use it. In this way, passing is advocated by the social environment and cultural context of Banarjoyo village. 
Riza Saputra

Actually, the Catholic of Banarjoyo village passing has a compatibility with Paramadhita's ${ }^{29}$ explanation saying that a Christian's passer adapts and imitates the tropes of Muslimness, yet, it has different kind of motivation. According to Paramadhita, the passer who imitates the tropes of other has a motivation to gain a reward and sympathetic gaze of the other. However, the Catholic of Banarjoyo who adopted the Qur'anic verses was not motivated with an intention to gain praise from another. In contrary, it was because they wanted to protect themselves as well as Muslims who utilized the Qur'an as an amulet. ${ }^{30}$

The Catholic who avoid from eating pork and dogs also shows the form of "passing," since they change or come out from what is usually done by their own community. Referring to this example the purpose of 'passing' has generated that is not only because for acquiring the benefits of other, but it is also for personal volition and importance. Such as Chris, who decided to do not eat pork and dog, he changed and passed his previous habit, since he learned and accepted the other opinion on prohibition of consumption of these meats. Moreover, He staunched to his principle that is not eating pork and dog, although, he was surrounded and scoffed by his family, community, and traditions.

Thirdly, adaptation, on learning and to cling, Paul O’ Ingram (2013), in his explanation of John Dunne's "passing over" writes that we are "on learning, not to cling," which means that individual passers may return to their own standpoint. However, the purpose of passing is not limited only to learn another standpoint, but it may also cling into another standpoint, since passing designates not only to learn another person way of life, but it may also to renew and to construct the prefer condition. Moreover, it does not cover the possibility that the individual passer presumably will feel comfortable with his new condition and identity, which later make him reluctant to come back to his previous condition.

\footnotetext{
${ }^{29}$ Intan Paramaditha, "Passing and Conversion Narratives: Ayat-Ayat Cinta and Muslim Performativity in Contemporary Indonesia," Asian Cinema 21 (2010):2.

${ }^{30}$ Abdullah, Najwa, and Mohamed Nawab Mohamed Osman. "Islamisation in the Indonesian media spaces new sites for a conservative push." Journal of Religious and Political Practice4, no. 3 (2018): 214-232.
} 
The notion of passing may help us to understand the identity of someone before they pass, the process why someone intends to pass, and the results after they have passed. As it is already indicated, the purpose of John Dunne's passing is to learn another person way of life. He said that it is must follow with another shift in standpoint "coming back." Dunne uses passing as a technique to learn the experiences of another, thus, it is obvious that an individual passer has to return to his own standpoint, because the aim is only to enrich individual passer's knowledge with another person's knowledge, experiences, worldview, and etc.

Passing as we already explained represents in a lot of discussion of human social phenomena. As Kroeger mentions that there are class passing, gender passing, age passing, ${ }^{31}$ even we usually mention that our times have passed, and some people have passed away. Passing is not designated only to move into a new condition, and then we can return easily to our previous condition. Dunne deciphers that there is a risk that may result from passing if the passer do not return to his own religion, and one of that risk is that the passer does not return to his previous standpoint.

It is true that if an individual moves and learn another religion will enrich his knowledge with other religious knowledge, experiences, worldview, and etc. However, passing as a form of adaptation does not intentionally aim for learning. The passer can gain the knowledge of another when he has embroiled and engaged with another. The passer willingness to act on behalf of the other should increase his understanding of the other and his empathy for the other. Moreover, adaptation may be a part of learning, and the passer may also cling with his new condition. Instead, the main purpose of adaptation is an adjustment of our behavior, habit, colloquial expressions, and etc.

\section{Conclusion}

The Christians and Catholicss adaptation with Muslims majority undergirds on three aspects of role taking: Firstly, is be a parallel, it means

${ }^{31}$ B. Kroeger, Passing: When People Can't Be Who They Are, 5. 
Riza Saputra

that the Christians and Catholics intertwine the relationship and connection with Muslims of Banarjoyo village. The rapport which is established by the Christians and Catholics with Muslims in Banarjoyo village has raised the familiarity among them. One of its examples is entwining silaturrabim and cooperation during Muslim's religious activities, Natal and the Ied days of Muslims.

Secondly, is associative, it means that the Christians and Catholics of Banarjoyo participate in Muslim activities. The Catholic and Christian's participation with Muslims religious activities has given a big contribution to the Christians and Catholics understanding of Islam. The result of this participation is more than to be parallel. Participation is an arena for the Christians and Catholics to understand their social partner closely. Thus, the process of this adaption sometimes results an imitation, feeling sympathy, empathy, and identification. For instance, the Christians and Catholics imitate Islamic expressions and Islamic principles, and memorizing verses of the Qur'an.

Thirdly, is cooperative, it means that the Christians and Catholics of Banarjoyo give their contribution and helping to the Muslims. The cooperation among Muslims, the Christians and Catholics of Banarjoyo village has result a way of behaving more supportively and the solution to solve the differences problem among them. The contribution of the Christians, Catholics and Muslims in cooperative action has contributed to the fascination among them. Cooperative actions have also built a positive assumption among the Christians, Catholics and Muslims in Banarjoyo village.

The dominant of Islamic culture in Banarjoyo village encourages the Christians and Catholics of Banarjoyo village to suit their habit as well as Muslims, including Islamic expressions and the principle of life. There are some reasons why the Christians and Catholics of Banarjoyo imitate the Islamic expressions: Firstly, is the Christians and Catholics ability of role taking, such as receiving the perspective of another has encouraged them to put themselves as well as Muslim do in Banarjoyo village, such as using the Qur'an as an amulet, fasting during the month of Ramadhan, and 
avoiding from the eating pork. The Catholics receive the perspective of Muslims that the function of the Qur'anic verses as an amulet is for protection from evil and crime. They also receive the perspective of Muslims that eating pork and dog will jeopardize their health.

Secondly, the function of imitation is to gain the same end, and the same behavior. By imitating the Islamic phrase in colloquial expressions, the Christians and Catholics can feel connected to the Muslims as their social partner. Imitation may serve as social glue, binding and bonding people together. Moreover, the function of imitation will increase the propensity to take the perspective of another person in term of understanding the meaning of their expressions.

Thirdly, the feeling of dissimilar from the dominant group of Muslims in Banarjoyo has led the Christians and Catholics to affiliate and assimilate with Musims, including imitating of their behaviors and colloquial expressions. This notion suggests that adaptation and imitation bring our attitudes in line with others. Fourthly, Catholic and Christian's participation in Muslim religious activities, such as, in Kendurenan, Aqiqahan, Tarawih, Takbiran, and Ngaji considered as the purport factor which constituted their imitation of Islamic expression and memorization of the Qur'an, Hadis, and Islamic prayer.

The general concept of passing as a method is encouraged by assuming the identity of another and acting as that of another. However, the Christians and Catholics of Banarjoyo do not assume their identity as Muslims. They still admit their identity as the Christianity, yet for the people who recently recognize them, they may misidentify and presume that their identity is Muslims, since their behavior and utilization of Islamic expressions.

The purpose concept of passing as a strategy generally aims to gain the privilege and reward from another group. However, the purpose of passing as a form of adaptation is because they receive the perspective and worldview of another. Thus, the purpose of passing does not intentionally to gain the privilege and reward from another, yet, the passer compares to another purpose and it may be the same as that another group intentions, such as using the Qur'an as an amulet for protection from the crimes and Islamic phrases in colloquial expressions, the Catholic of Banarjoyo village 
adopt this Muslim's local worldview that the verses of the Qur'an may be an inter-mediatory tool for protection, and Islamic phrase as a part of inter-mediatory communication. The Christians and Catholics' utilization of the Qur'an as an amulet and Islamic phrase are not intended by them as a way to gain the reward from Muslim, but, for themselves protection.

Another purpose of passing is for pretending in order to disguise or suppress another group. However, the purpose of passing as a form of adaptation does not cover the individual passers identity. The Christians and Catholics realize that their identity is different from the dominant group of Muslims. Thereof, by passing, such as imitation of Islamic expressions, the Christians and Catholics can feel connected to the Muslims. Adaptation may be a part of learning, and the passer may cling with that part of learning. However, the main purpose of passing as an adaptation is an adjustment in order to receive an acceptance and recognizance from another group. Thus, the rapport between one group with another can intertwine harmoniously.

\section{References}

Abdullah, Najwa, and Mohamed Nawab Mohamed Osman. "Islamisation in the Indonesian media spaces new sites for a conservative push." Journal of Religious and Political Practice4, no. 3 (2018): 214-232.

Adams, Katharine S., Jeremy R. Tost, Mark A. Whatley, Meghan C. Brown, Brendan J. Dochney, Jessica M. Taylor, and Mary H. Neal.

"Relationship of Christian beliefs to attitudes toward people with mental illness." American journal of psychotherapy 71, no. 3 (2018): 104109.

Barberia, Itxaso, Ramon Oliva, Pierre Bourdin, and Mel Slater. "Virtual mortality and near-death experience after a prolonged exposure in a shared virtual reality may lead to positive life-attitude changes." PloS one 13, no. 11 (2018): e0203358.

Burke, Peter J. “The Self: Measurement Requirements from an Interactionist Perspective." Social Psychology Quarterly 43, no. 1 (1980): 18-29. https://doi.org/10.2307/3033745. 
Passing as a Form of Adaptation:

The Islamic Nuances of the Christians and Catholics

Butler, Janine. "The Visual Experience of Accessing Captioned Television and Digital Videos." Television \& New Media (2019): 1527476418824805.

Butler, Judith. Gender Trouble: Feminism and the Subversion of Identity. Routledge, 2011.

Caughie, Pamela L., Emily Datskou, and Rebecca Parker. "Storm clouds on the horizon: feminist ontologies and the problem of gender." Feminist Modernist Studies 1, no. 3 (2018): 230-242.

Caughie, Pamela L. Passing and Pedagogy: The Dynamics of Responsibility. Urbana, Ill.: University of Illinois Press, 1999.

Caughie, Pamela L. "Passing as Modernism." Modernism/Modernity 12, no. 3 (September9, 2005): 385-406. https://doi.org/10.1353/mod.2005.0079.

Fernández-Berrocal, Pablo, and Carlos Santamaría. "Mental Models in Social Interaction." The Journal of Experimental Education 74, no. 3 (April 1, 2006): 227-48. https://doi.org/10.3200/JEXE.74.3.227-248.

Hechavarría, Diana M. "Mother nature's son? The impact of gender socialization and culture on environmental venturing." International Journal of Gender and Entrepreneurship 8, no. 2 (2016): 137-172.

Hefner, Robert W. "Introduction: Indonesia at the crossroads: imbroglios of religion, state, and society in an Asian Muslim nation." In Routledge Handbook of contemporary Indonesia, pp. 3-30. Routledge, 2018

Heyes, Cecilia. “Automatic Imitation.” Psychological Bulletin, 463-483, 137 (2011). https://doi.org/DOI: 10.1037/a0022288.

Hostert, Anna Camaiti. Passing: A Strategy to Dissolve Identities and Remap Differences. Translated by Christine Marciasini. 1 edition. Madison N.J.: Fairleigh Dickinson Univ Pr, 2007.

Knitter, Paul F. "Christian Attitudes Toward Other Religions: The Challenge of Commitment and Openness." Prajñā Vihära 5, no. 1 (2004).

Kroeger, B. Passing: When People Can't Be Who They Are. United States: Public Affairs, 2003. 
Riza Saputra

Mang, Pum Za. "The Politics of Religious Conversion among the Ethnic Chin in Burma." Studies in World Christianity 24, no. 3 (2018): 188211.

Marie Wong, Stephanie. "A Society Apart: Rural Chinese Catholics and the Historiography of 'Otherness'." Studies in World Christianity 22, no. 2 (2016): 86-104.

Mercadante, Linda. "Belief without borders: Inside the minds of the spiritual but not religious." In Being Spiritual but Not Religious, pp. 110-127. Routledge, 2018.

Paramaditha, Intan. "Passing and Conversion Narratives: Ayat-Ayat Cinta and Muslim Performativity in Contemporary Indonesia," Asian Cinema 21 (2010):2.

Polley, Gabriel. "From Karm al-Khalil to Kerem Avraham: A British SettlerColonial Outpost Near Jerusalem in the Nineteenth Century." Journal of Holy Land and Palestine Studies 18, no. 1 (2019): 51-73.

Rosello, Mireille. "Dissident or Conformist Passing: Merzak Allouache's Chouchou." South Central Review 28, no. 1 (May 27, 2011): 2-17. https://doi.org/10.1353/scr.2011.0003.

Sands, Justin. "Passing through customs: Merold Westphal, Richard Kearney, and the methodological boundaries between philosophy of religion and theology." Religions 7, no. 7 (2016): 83.

Sharma, Rajendra Kumar. Social Changes and Social Control. New Delhi: Atlantic Publishers \& Distributors, 2007.

Silvermint, Daniel. "Passing as privileged." Ergo, an Open Access Journal of Philosophy 5 (2018).

Thompson, Ayanna. Passing Strange: Shakespeare, Race, and Contemporary America by Ayanna Thompson. Oxford University Press, 1700.

Watson, Nick J., and Andrew Parker. "The mystical and sublime in extreme sports: Experiences of psychological well-being or Christian revelation?." Studies in World Christianity21, no. 3 (2015): 260-281

Wetzorke, Robert. Passing and the Problem of Identity in Afro-American Literature: A Study of N. Larsen and J.W. Johnson. GRIN Verlag, 2010. 